Article

\title{
Structural Equation Modeling for Mobile Learning Acceptance by University Students: An Empirical Study
}

\author{
Quadri Noorulhasan Naveed ${ }^{1, *(\mathbb{D}}$, Mohammad Mahtab Alam ${ }^{2}\left(\mathbb{D}\right.$ ) and Nasser Tairan ${ }^{1}$ (D) \\ 1 Department of Computer Science, College of Computer Science, King Khalid University, \\ Abha 62529, Saudi Arabia; nmtairan@kku.edu.sa \\ 2 Department of Basic Medical Science, College of Applied Medical Science, King Khalid University, \\ Abha 62529, Saudi Arabia; mmalam@kku.edu.sa \\ * Correspondence: qnaveed@kku.edu.sa; Tel.: +966-17-2419357
}

Received: 15 September 2020; Accepted: 3 October 2020; Published: 17 October 2020

\begin{abstract}
Advanced mobile devices and global internet services have enhanced the usage of smartphones in the education sector and their potential for fulfilling teaching and learning objectives. The current study is an attempt to assess the factors affecting mobile learning acceptance by Saudi university students. A theoretical model of mobile learning acceptance was developed based on the technology acceptance model (TAM) and the unified theory of acceptance and use of technology (UTAUT) model. Theoretically, five independent constructs were identified as most contributory towards the use of mobile learning and tested empirically. Data were collected through an online survey and analyzed using SmartPLS. The results of the study indicate that four constructs were significantly associated with mobile learning acceptance: perceived usefulness $(\beta=0.085, \mathrm{t}=2.201$, and $p=0.028)$, perceived ease of use $(\beta=0.031, \mathrm{t}=1.688$, and $p=0.013)$, attitude $(\beta=0.100, \mathrm{t}=3.771$, and $p=0.037)$, and facilitating conditions $(\beta=0.765, \mathrm{t}=4.319$, and $p=0.001)$. On the other hand, social influence was insignificant $(\beta=-0.061, \mathrm{t}=0.136$, and $p=0.256$ ) for mobile learning acceptance. The contribution of social influence towards the use of mobile learning was negative and insignificant; hence, it was neglected. Thus, finally, four constructs (perceived usefulness, perceived ease of use, attitude, and facilitating conditions) were considered as important determinants of mobile learning acceptance by university students.
\end{abstract}

Keywords: mobile learning; M-Learning; structural equation modeling; technology acceptance model; unified theory of acceptance and use of technology model; university students

\section{Introduction}

In the past two decades, researchers have initiated an exploration of online education and its revolutionary potential, which is backed by expanding digital-technology-based online learning using the Internet [1,2]. Smartphones have become an indispensable key component in the learning environment by linking instructors, students, and learning resources, independent of time and place [3]. Learning through mobiles is described as a novel form of teaching-learning that is assisted by smartphones, involving immensely powerful communication technology and the smart architecture of user interfaces [4]. New technology-enabled smartphones are helping students and instructors to access mobile learning management systems (mLMS), which have fueled the massive growth of online educational initiatives and enabled new capabilities in teaching and learning applications [1].

The competitive and hi-tech environment in higher education has forced academic institutions to adopt the latest technology and delivery systems for their survival. As of now, universities are 
enforcing more technology-based advanced syllabuses with advanced software to enhance the quality of materials delivered to students and to try to combat global competition by gaining a technical advantage. Hence, this has motivated us to investigate the technological developments in studying and the future scope and acceptance of mobile learning, particularly for big universities [5]. The results of some research studies indicate that mobile learning with the social approach is expanding globally; numerous universities are backing huge marketing initiatives to publicize mobile learning $[5,6]$. Several studies have reported that universities are on the way to using Mobile Learning (M-Learning) along with Electronic Learning (E-Learning). Moreover, $94 \%$ of universities have incorporated some form of M-Learning into their teaching-learning system [5,7].

The acceptance of mobile learning by students is essential to making the M-Learning systems successful in university education. Therefore, empirical research analysis addressing this growing trend towards the adoption of mobile learning by students is essential. Saudi Arabia is a prominent country with good communications infrastructure and many smartphone users. Taking into account the advanced communications infrastructure, university students in Saudi Arabia can opt for ever faster and better mobile services. The number of smartphone users in Saudi Arabia is expected to reach 20.5 million by 2020 and 21.3 million by 2023 [8].

M-Learning is a sub-set of E-Learning, which provides added advantages over E-Learning as it builds self-confidence, self-esteem, and the capacity to remain more focused for longer periods. Very few studies have been conducted to assess the factors that affect mobile learning acceptance by university students at a global level in general, and more particularly in Saudi Arabia. The current study is an attempt to fill the prevailing research gap by conceptual modeling on mobile learning acceptance and its determinants and empirical testing of the proposed conceptual model.

\section{Conceptual Framework of Study}

To achieve significant execution rates for mobile learning applications at the university level, acceptability, usefulness, and university support for proper facilities for mobile learning usage and adoption attitude factors need to be addressed. Several researchers have identified many factors that can predict M-Learning acceptance by students [3]. Extensive literature reviews have revealed the important trends, constructs, concepts, theories, and technology adoption models for mobile learning usage at the university level. Several studies have applied the technology acceptance model (TAM) $[4,9,10]$ and the unified theory of acceptance and use of technology (UTAUT) model [11-13]. Some research has modified these models with other research models such as the theory of planned behavior [14], DeLone and McLean information systems success model [15], task-technology fit [16] and expectation-confirmation theory [17]. The latest updates on mobile learning acceptance and a detailed summary of different researchers are presented in Appendix A Table A1.

The key factors are searched, analyzed, and collected for further assessment of their role in the adoption of mobile learning. Eighteen different construct items are sorted and listed for further analysis by decision-makers who are expert practitioners in E-Learning teaching-learning systems. A single decision-maker may give a biased personal opinion, which could lead to inaccurate judgment. To remove biases and vagueness in decision-making, four expert Decision Makers (DMs) who knew the information system and have more than five years of E-Learning teaching experience were invited to identify the final constructs.

The nominal group technique was developed to conduct group brainstorming with an expert in order to identify areas of mutual agreement on the importance of issues. The nominal group technique was adopted to combine TAM [18], the theory of technology acceptance [14], and UTAUT [19] in order to propose a mobile learning usage model. Out of 18 identified constructs from TAM, UTAUT, and the theory of technology acceptance, five independent constructs were shortlisted with the help of the nominal group technique as determinants of mobile learning acceptance, as shown in Figure 1. 


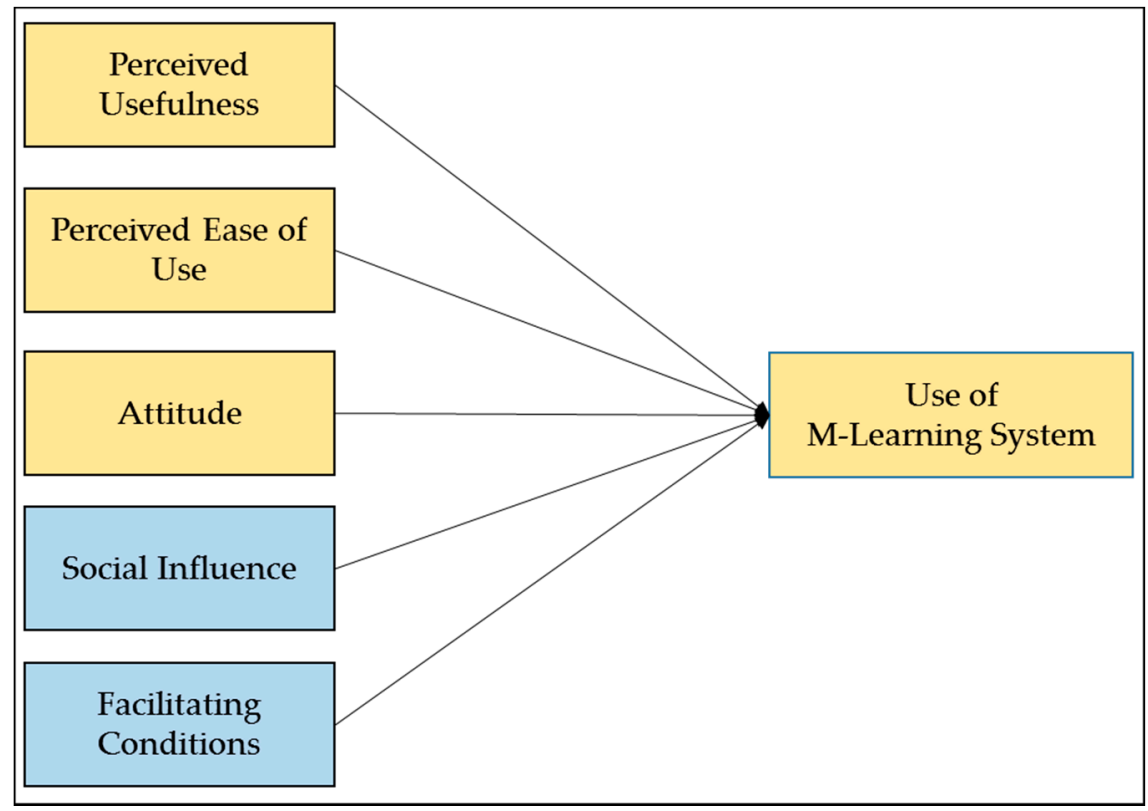

Figure 1. Mobile Learning usage model.

These factors were selected with a two-stage selection process. Firstly, a systematic review of the literature $[9,11,15,20,21]$ was conducted to find out the factors affecting mobile learning. Previous studies $[13,15,22]$ commonly used perceived usefulness, perceived ease of use, attitude, social influence, and facilitating conditions. Secondly, expert opinions were taken at the local level to include these factors in an assessment of mobile learning factors. The suggested model plays a significant role in investigating the effect of constructs on the intention of student use of M-Learning. Perceived usefulness, perceived ease of use, and attitude make up the TAM construct, whereas social influence and facilitating conditions make up that of UTAUT.

\subsection{Perceived Usefulness}

The construct's perceived usefulness is particularly associated with performance at work, quality, and reliability, and is defined as "the degree to which a person believes that using a particular system would enhance their job performance" [18]. It measures the extent to which someone considers technology as benefiting them in their intentions. By incorporating this construct into TAM, a usefulness factor is presumed to significantly affect the behavioural demand [5]. Hence, the subsequent hypothesis arises:

Hypothesis 1 (H1). Perceived usefulness positively influences the use of the M-Learning system factor.

\subsection{Perceived Ease of Use}

Perceived ease of use refers to the decision of a person who uses a given system with no or little effort. This factor is very important in the acceptance of a new technological system; it plays a vital role and is pretty obvious in the usage of the new system by individuals [5]. This leads to the following hypothesis:

Hypothesis 2 (H2). Perceived ease of use positively influences the use of the M-Learning system factor. 


\subsection{Attitude}

Attitude is a psychological and emotional entity that describes a person's beliefs and accumulated state of mind, which are formed by their experiences. An individual's attitude towards a particular behaviour is essentially an individual's good or bad feeling about the results of a particular behaviour [14]. It is the socially conditioned mindset of a person concerning a value, and is caused by a sensitive action towards an individual, position, thing, or event (the object of the attitude), which in turn affects the thoughts and feelings of the individual. Some studies suggest a learner's attitude towards M-Learning influences their behaviour in terms of using the system $[16,23]$. The attitude of a person towards a specific behaviour is equal to the overall view of the actions of that person [24]. Thus, this research study suggests the following hypothesis.

Hypothesis 3 (H3). Attitude has a significant effect on the use of the M-Learning system factor.

\subsection{Social Influence}

Peers affect how people use mobile devices [23]. Organizational ethical culture and social norms in the use of new technology are considered to be the social influence construct and are defined as "the degree to which an individual perceives that it is important others believe they should use the new system" [19]. In the context of literature related to education, social influence and usage of the learning environment exhibit a positive relationship [1]. The social influence may be defined as "the degree to which individuals perceive that others' belief is important in their usage of mobile learning" and focuses on the influence of the university, college, instructors, and the students' peers. Based on the above literature review, this has led to the following hypothesis.

Hypothesis 4 (H4). Social influence positively influences the use of the M-Learning system factor.

\subsection{Facilitating Conditions}

Facilitating conditions include the important factors that help all the stakeholders to do their work easily. The term involves different conditions, such as good quality infrastructure to help with use of the system, specialized training, knowledge, as well as support and assistance from the organization [13]. It is defined as "the degree to which an individual believes that an organizational and technical infrastructure exists to support the use of the system" [19]. This leads to the following hypothesis:

Hypothesis 5 (H5). Facilitating conditions positively influence the use of the M-Learning system factor.

\subsection{Use of M-Learning System}

The factor relating to the use of an M-Learning system refers to individual desires or individual behavioural intent to use that system. It also reflects the efficacy of a person's actions in terms of a specific procedure. Use of the system is based on character and personal values, utility, ease of use, and confidence [10].

\section{Research Methodology}

\subsection{Study Design}

The main purpose of the study was to develop a concrete and concise conceptual model for evaluating mobile learning acceptance, along with its determinants. The multistage research design was used to conceptualize, validate, and examine the proposed model. Firstly, the study was exploratory in nature by screening the 18 previously used items to assess mobile learning acceptance and by 
extracting five independent constructs to determine the acceptance of mobile learning by using the nominal group technique approach. Secondly, the study was empirical in nature by empirically testing the proposed conceptual model of mobile learning acceptance.

\subsection{Research Instruments}

The research instrument for the present study was a questionnaire survey, as shown in Appendix A Table A2. The questionnaire survey included 3 different sections. Section 1 contained the objectives and written consent about confidentiality relating to information. Section 2 consisted of the respondent profile demographic items, while factors relating to the usage of M-Learning were discussed in Section 3. The questionnaire survey had two different types of responses, namely multiple choice answers and a 5-point Likert scale. The validity of the research instrument in the present study was assessed through three levels. Firstly, a literature review was used to validate and support the required construct or factor selection for investigation. This referred to prior work carried out by peers in the same field [25], which had been subjected to peer or expert evaluation. A nominal group technique approach was applied to screen explanatory variables.

\subsection{Sample Size}

To test the theoretically developed model, data were collected from currently enrolled students of King Khalid University using a structured online Google survey. The sample size was determined by using the following formula.

$$
S S=\frac{z^{2}(p)(q)}{e^{2}}
$$

where $S S=$ Sample Size; $Z=1.96$ (95\% confidence level); $P$ = prevalence level ( 0.5 used for sample size needed); $Q=(1-p) ; E=$ error term (0.05). By inserting values into the formula, the sample size would be:

$$
\begin{gathered}
S S=\frac{1.96^{2}(0.50)(0.50)}{0.05^{2}} \\
S S=\frac{3.8416(0.25)}{0.0025} \\
S S=\frac{0.9604}{0.0025}
\end{gathered}
$$

Sample Size $=384.16$

\subsection{Study Variables}

Attitude, perceived usefulness, social influence, perceived ease of use, and facilitating conditions were the explanatory or independent variables. The mobile learning system was the response or dependent variable.

\subsection{Data Analysis}

Structured equation modeling (SEM) with the help of SmartPLS (v.3.3.2) was used to empirically test the theoretically proposed model. Outer loading was used to test indicator reliability, Cronbach's alpha was used to check the reliability and internal consistency of the data, and the composite reliability and validity were checked with the help of the average variance extracted (AVE) and Heterotrait-Monotrait ratio analysis. Multicollinearity was checked through the variance inflation factor.

\section{Analysis and Findings}

The study used SEM as the statistical tool for the data for validation and analysis. The model, as shown in Figure 2, was constructed with the help of SmartPLS 3.3.2. The basic elements used in 
this study are shown in the demographic profile in Table 1. The model was evaluated using indicator reliability with the help of outer loadings, reliability and internal consistency reliability with the help of Cronbach's alpha, and composite reliability and validity with the help of the average variance extracted and Heterotrait-Monotrait ratio.

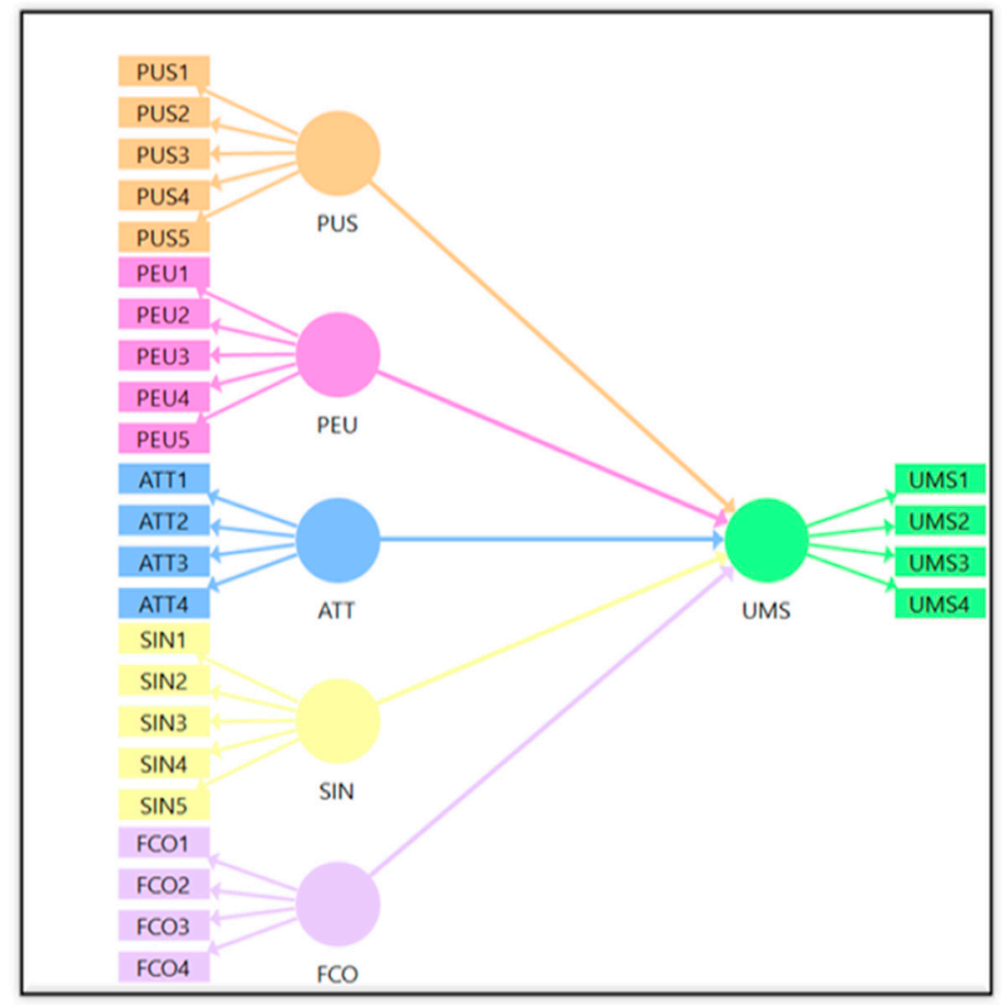

Figure 2. M-Learning model.

As per the suggestions in previous studies [26], if the outer loading is greater than 0.70 , the indicators should be retained. If the outer loading is from 0.40 to 0.70 , then the relationship with composite reliability and the AVE should be examined. If composite reliability and the AVE meet the criterion then the indicators should be retained, and if the value of the outer loading is less than 0.40 the item should be removed for further analysis. As presented in Table 2, all the factor loadings were more than 0.70, except one item-facilitating conditions (FCO1-0.618). However, the composite reliability and AVE were 0.906 and 0.710 , respectively, which is higher than the desired level needed to retain the item for any construct. All items were retained in their original form to measure M-Learning usage.

Cronbach's alpha, composite reliability, and average variance extracted were calculated to test the internal consistency and validity of the model (as depicted in Table 2). The results for the data in Table 2 depict that Cronbach's alpha and composite reliability values for all constructs were greater than 0.70 , which meets the standard validity criterion [26] for further analysis. All constructs were reliable for the proposed model. AVE (AVE $\geq 0.50$ ) values for all constructs met the standard validity criterion [27]; therefore, all five constructs were considered appropriate for further analysis.

As presented in Table 3, the results for the correlation matrix for the Fornell-Larcker test clearly indicate that the diagonal values are greatest for a certain construct as compared with the other values. As proposed by [28], Heterotrait-Monotrait (HTMT) analysis was carried out to examine discriminant validity. The HTMT correlation is the relationship for the same construct with a different time frame. The results for the Heterotrait-Monotrait analysis, as shown in Table 4, show that the value of the correlation for the same construct is below the acceptable range (HTMT < 0.90). 
Table 1. Demographic profile.

\begin{tabular}{|c|c|c|c|c|}
\hline Items & Description & $\mathbf{N}$ & $\%$ & Cumulative $\%$ \\
\hline \multirow{2}{*}{ Gender } & Male & 172 & 44.6 & 44.6 \\
\hline & Female & 214 & 55.4 & 100.0 \\
\hline \multirow{4}{*}{ Age (years) } & Under 18 & 84 & 21.8 & 21.8 \\
\hline & $18-21$ & 102 & 26.4 & 48.2 \\
\hline & $22-25$ & 128 & 33.2 & 81.3 \\
\hline & Above 25 & 72 & 18.7 & 100.0 \\
\hline \multirow{4}{*}{ Knowledge of M-Learning } & Excellent & 189 & 49.0 & 49.0 \\
\hline & Good & 118 & 30.6 & 79.5 \\
\hline & Average & 54 & 14.0 & 93.5 \\
\hline & Poor & 25 & 6.5 & 100.0 \\
\hline \multirow{5}{*}{$\begin{array}{l}\text { Satisfaction level with } \\
\text { current M-Learning services }\end{array}$} & Highly Satisfied & 123 & 31.9 & 31.9 \\
\hline & Satisfied & 156 & 40.4 & 72.3 \\
\hline & Neutral & 49 & 12.7 & 85.0 \\
\hline & Dissatisfied & 30 & 7.8 & 92.7 \\
\hline & Highly Dissatisfied & 28 & 7.3 & 100.0 \\
\hline \multirow{13}{*}{ Area of study } & College of Shariah & 31 & 8.0 & 8.0 \\
\hline & College of Computer Science & 64 & 16.6 & 24.6 \\
\hline & College of Engineering & 56 & 14.5 & 39.1 \\
\hline & College of Languages and Translation & 46 & 11.9 & 51.0 \\
\hline & College of Medicine & 52 & 13.5 & 64.5 \\
\hline & College of Dentistry & 21 & 5.4 & 69.9 \\
\hline & College of Pharmacy & 22 & 5.7 & 75.6 \\
\hline & College of Applied Medical Science & 18 & 4.7 & 80.3 \\
\hline & College of Education & 19 & 4.9 & 85.2 \\
\hline & College of Humanities & 16 & 4.1 & 89.4 \\
\hline & College of Business & 23 & 6.0 & 95.3 \\
\hline & Community College & 13 & 3.4 & 98.7 \\
\hline & Others & 5 & 1.3 & 100.0 \\
\hline \multirow{4}{*}{$\begin{array}{l}\text { Daily amount of mobile } \\
\text { device usage }\end{array}$} & Less than $1 \mathrm{~h}$ & 72 & 18.7 & 18.7 \\
\hline & $1-2 \mathrm{~h}$ & 103 & 26.7 & 45.3 \\
\hline & $3-4 \mathrm{~h}$ & 107 & 27.7 & 73.1 \\
\hline & More than $4 \mathrm{~h}$ & 104 & 26.9 & 100.0 \\
\hline
\end{tabular}

Path coefficients ( $\beta$ values) were calculated using SmartPLS 3.2.9, which are presented in Figure 3. To test the significance level of the path coefficient ( $\beta$ values), the t-test values along with their significance values were calculated and are presented in Table 5 . There are two ways to interpret the $p$-values depending on the drafting of the research hypothesis. Firstly, if the research hypothesis is defined in negative terms and the $p$-value is less than 0.05 , then the researcher should reject the research hypothesis. Secondly, if the research hypothesis is defined in positive terms and the $p$-value is less than 0.05 , then the researcher should accept the research hypothesis with a $5 \%$ level of significance in both cases. The current study adopted the second approach. As presented in the path coefficient in Figure 3, 76.1\% of the use of M-Learning was explained by the five constructs, namely attitude, perceived usefulness, social influence, perceived ease of use, and facilitating conditions.

The outcome of path coefficient ( $\beta$ values), t-test statistics, and $p$-values presented in Table 5 demonstrate that the relationship between social influence and the use of an M-Learning system is not significant at the $5 \%$ level of significance. All the other hypotheses were accepted, as their $p$-values were less than 0.05 and $t$-values were greater than 1.65 .

To detect multicollinearity, the variance inflation factor (VIF) was used as outcome was presented in Table 6. A common threshold value is above 10 [29]. The common threshold value is 5 in covariance-based SEM [30]. A cut-off variance inflation factor threshold of 3.3 has been recommended to detect multicollinearity [31]. 
Table 2. Outer Loading (OL), Reliability, Composite Reliability (CR), and Average Variance Extracted (AVE).

\begin{tabular}{|c|c|c|c|c|c|}
\hline Construct & Items & Loading OL $\geq 0.70$ & Cronbach's Alpha $\alpha \geq 0.70$ & $\mathrm{CR} \geq 0.70$ & AVE $\geq 0.50$ \\
\hline \multirow{5}{*}{ Perceived Usefulness } & PUS1 & 0.892 & \multirow{5}{*}{0.858} & \multirow{5}{*}{0.899} & \multirow{5}{*}{0.644} \\
\hline & PUS2 & 0.874 & & & \\
\hline & PUS3 & 0.787 & & & \\
\hline & PUS4 & 0.780 & & & \\
\hline & PUS5 & 0.656 & & & \\
\hline \multirow{5}{*}{ Perceived Ease of Use } & PEU1 & 0.743 & \multirow{5}{*}{0.862} & \multirow{6}{*}{0.900} & \multirow{6}{*}{0.644} \\
\hline & PEU2 & 0.859 & & & \\
\hline & PEU3 & 0.809 & & & \\
\hline & PEU4 & 0.809 & & & \\
\hline & PEU5 & 0.790 & & & \\
\hline \multirow{4}{*}{ Attitude } & ATT1 & 0.830 & \multirow{4}{*}{0.854} & & \\
\hline & ATT2 & 0.833 & & \multirow{3}{*}{0.901} & \multirow{3}{*}{0.694} \\
\hline & ATT3 & 0.842 & & & \\
\hline & ATT4 & 0.829 & & & \\
\hline \multirow{5}{*}{ Social Influence } & SIN1 & 0.846 & \multirow{6}{*}{0.930} & \multirow{6}{*}{0.947} & \multirow{6}{*}{0.781} \\
\hline & SIN2 & 0.897 & & & \\
\hline & SIN3 & 0.893 & & & \\
\hline & SIN4 & 0.912 & & & \\
\hline & SIN5 & 0.869 & & & \\
\hline \multirow{4}{*}{ Facilitating Conditions } & FCO1 & 0.618 & & & \\
\hline & $\mathrm{FCO} 2$ & 0.890 & \multirow{3}{*}{0.856} & \multirow{3}{*}{0.906} & \multirow{3}{*}{0.710} \\
\hline & FCO3 & 0.917 & & & \\
\hline & $\mathrm{FCO} 4$ & 0.909 & & & \\
\hline \multirow{4}{*}{ Use of M-Learning System } & UMS1 & 0.914 & \multirow{4}{*}{0.904} & \multirow{4}{*}{0.933} & \multirow{4}{*}{0.778} \\
\hline & UMS2 & 0.922 & & & \\
\hline & UMS3 & 0.883 & & & \\
\hline & UMS4 & 0.804 & & & \\
\hline
\end{tabular}

Table 3. Fornell-Larcker discriminant validity.

\begin{tabular}{ccccccc}
\hline Construct & $\mathbf{1}$ & $\mathbf{2}$ & $\mathbf{3}$ & $\mathbf{4}$ & $\mathbf{5}$ & $\mathbf{6}$ \\
\hline Attitude & 0.833 & & & & & \\
Facilitating Conditions & 0.705 & 0.843 & & & & \\
Perceived Ease of Use & 0.703 & 0.664 & 0.803 & & & \\
Perceived Usefulness & 0.518 & 0.608 & 0.657 & 0.802 & & \\
Social Influence & 0.814 & 0.688 & 0.661 & 0.499 & 0.884 & \\
Use of M-Learning System & 0.656 & 0.866 & 0.625 & 0.592 & 0.61 & 0.882 \\
\hline
\end{tabular}

Table 4. Heterotrait-Monotrait correlation matrix.

\begin{tabular}{lccccc}
\hline \multicolumn{1}{c}{ Construct } & $\mathbf{1}$ & $\mathbf{2}$ & $\mathbf{3}$ & $\mathbf{4}$ & $\mathbf{5}$ \\
\hline Attitude & & & & & \\
Facilitating Conditions & 0.851 & & & & \\
Perceived Ease of Use & 0.799 & 0.784 & & & \\
Perceived Usefulness & 0.609 & 0.709 & 0.777 & & \\
Social Influence & 0.910 & 0.810 & 0.726 & 0.560 & \\
Use of M-Learning System & 0.740 & 0.979 & 0.705 & 0.671 & 0.661 \\
\hline
\end{tabular}




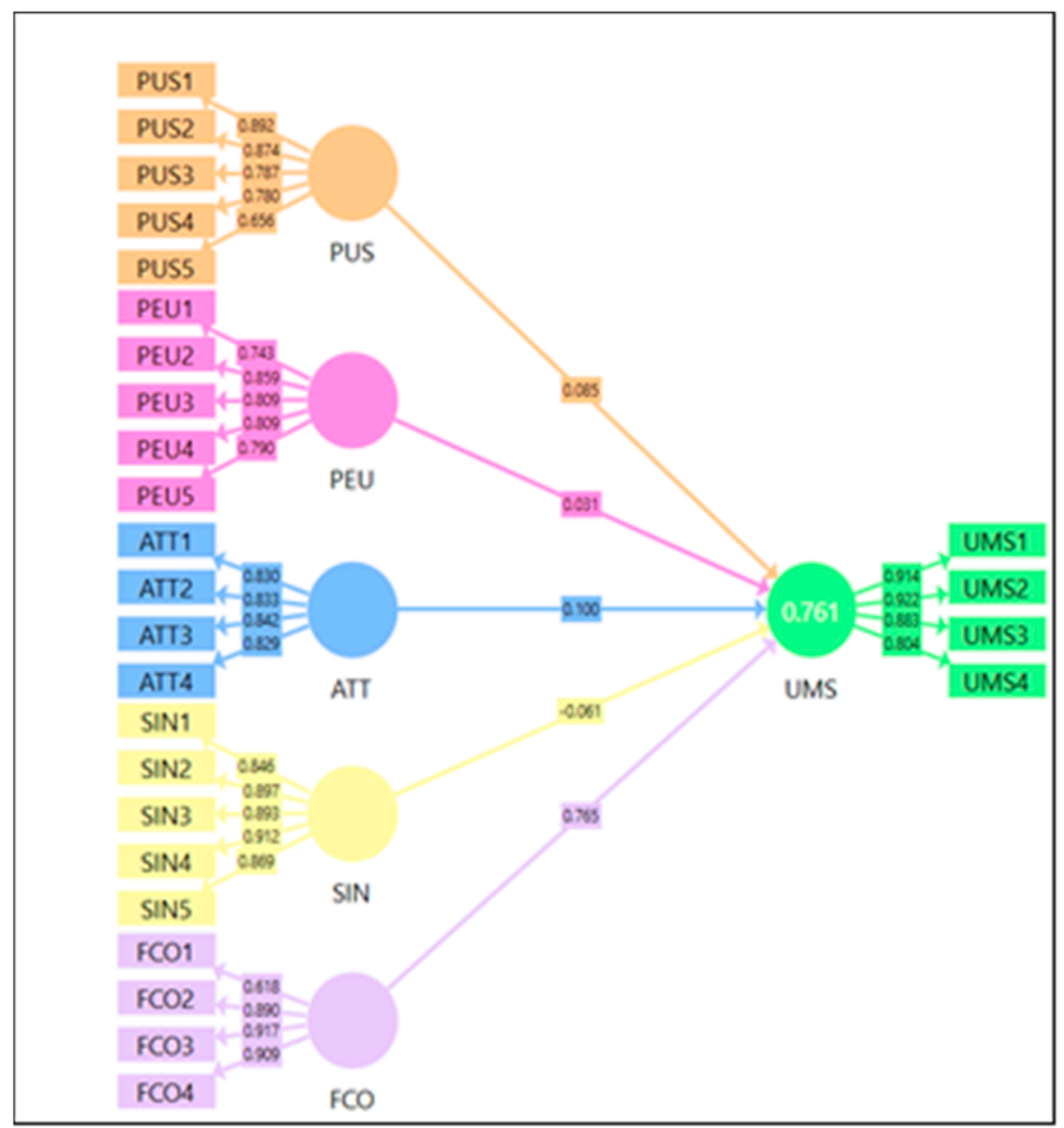

Figure 3. Structural path model coefficient.

Table 5. $t$-test values with significance levels.

\begin{tabular}{|c|c|c|c|c|c|}
\hline Hypothesis & Path & $\begin{array}{c}\text { B } \\
\text { Value }\end{array}$ & $\begin{array}{c}T \\
\text { Statistics }\end{array}$ & $\begin{array}{c}P \\
\text { Values }\end{array}$ & Decision \\
\hline H1 & Perceived Usefulness -> Use of M-Learning System & 0.085 & 2.201 & 0.028 & Accept \\
\hline $\mathrm{H} 2$ & Perceived Ease of Use -> Use of M-Learning System & 0.031 & 1.688 & 0.018 & Accept \\
\hline H3 & Attitude -> Use of M-Learning System & 0.100 & 3.771 & 0.037 & Accept \\
\hline $\mathrm{H} 4$ & Social Influence -> Use of M-Learning System & -0.061 & 0.136 & 0.256 & Reject \\
\hline H5 & Facilitating Conditions -> Use of M-Learning System & 0.765 & 4.319 & 0.001 & Accept \\
\hline
\end{tabular}


Table 6. Variance Inflation Factor (VIF).

\begin{tabular}{|c|c|c|c|c|}
\hline \multicolumn{2}{|c|}{ Outer VIF Values } & \multicolumn{2}{|c|}{ Inner VIF Values } & \multirow{2}{*}{ Decision } \\
\hline Items & VIF & Constructs & VIF & \\
\hline ATT1 & 1.909 & \multirow{5}{*}{ Attitude } & \multirow{5}{*}{2.656} & \multirow{5}{*}{ Under minimum cut-off value 3.3} \\
\hline ATT2 & 2.093 & & & \\
\hline ATT3 & 1.949 & & & \\
\hline ATT4 & 1.934 & & & \\
\hline FCO1 & 1.293 & & & \\
\hline $\mathrm{FCO} 2$ & 2.256 & \multirow{5}{*}{ Facilitating Conditions } & \multirow{5}{*}{2.562} & \multirow{5}{*}{ Under minimum cut-off value 3.3} \\
\hline $\mathrm{FCO} 3$ & 2.875 & & & \\
\hline $\mathrm{FCO} 4$ & 2.978 & & & \\
\hline PEU1 & 1.735 & & & \\
\hline PEU2 & 1.322 & & & \\
\hline PEU3 & 2.803 & \multirow[t]{5}{*}{ Perceived Ease of Use } & \multirow[t]{5}{*}{2.699} & \multirow[t]{5}{*}{ Under minimum cut-off value 3.3} \\
\hline PEU4 & 2.293 & & & \\
\hline PEU5 & 2.218 & & & \\
\hline PUS1 & 1.968 & & & \\
\hline PUS2 & 1.278 & & & \\
\hline PUS3 & 1.911 & \multirow[t]{5}{*}{ Perceived Usefulness } & \multirow[t]{5}{*}{1.942} & \multirow[t]{5}{*}{ Under minimum cut-off value 3.3} \\
\hline PUS4 & 1.817 & & & \\
\hline PUS5 & 1.446 & & & \\
\hline SIN1 & 2.640 & & & \\
\hline SIN2 & 2.414 & & & \\
\hline SIN3 & 1.365 & \multirow[t]{4}{*}{ Social Influence } & \multirow[t]{4}{*}{2.264} & \multirow[t]{4}{*}{ Under minimum cut-off value 3.3} \\
\hline SIN4 & 1.862 & & & \\
\hline SIN5 & 2.933 & & & \\
\hline UMS1 & 2.745 & & & \\
\hline UMS2 & 2.288 & \multirow{3}{*}{ Use of M-Learning ystem } & \multirow{3}{*}{-} & \multirow{3}{*}{ Under minimum cut-off value 3.3} \\
\hline UMS3 & 2.816 & & & \\
\hline UMS4 & 1.940 & & & \\
\hline
\end{tabular}

\section{Discussion}

The outcome of the study strongly supports hypothesis 1 , which indicates that perceived usefulness and use of an M-Learning system are positively associated with each other. In other words, M-Learning is prompt and beneficial in achieving learning objectives and increasing learners' efficiency. It provides instant access that improves association among instructors, students, and peer groups. These factors also boost intentions towards using an M-Learning system. Higher perceived usefulness leads to greater use of the M-Learning system due to the nature of the relationship. Different researchers have studied the importance of perceived usefulness in the context of M-Learning. The finding of this study confirms the previous findings $[4,5,9,14,22,32]$.

Hypothesis 2 is supported and accepted. In other words, items for perceived ease of use, such as the M-Learning system, are flexible and easy to use. The use of M-Learning requires very little effort-it is stress-free to become a skilful user and easy to access data using M-Learning systems. Easy-to-use M-Learning tools also provide guidance that motivates people to use the M-Learning system. Higher perceived ease of use leads to higher use of M-Learning. Other researchers $[4,5,9,10,14,22,32]$ have studied the effect of perceived ease of use on M-Learning. Our finding is similar to the previous findings.

Hypothesis 3 is supported and accepted; it states that there is a highly significant positive correlation between attitude and use of an M-Learning system. The items for attitude, such as how pleasant it is to work with the M-Learning system, whether it makes work more fascinating, whether working with the system is enjoyable, and whether using the system is a good idea, have a strong influence on the use of an M-Learning system. The positive attitude of the learners influences them towards using the M-Learning system. Several researchers $[4,14,33]$ have also studied the effect of 
the user's attitude on M-Learning adoption. A more positive attitude of learners towards an M-learning system leads to greater use of the M-Learning system. Our finding is similar to the previous findings.

Hypothesis 4 was rejected, which demonstrates that social influence and the use of M-Learning systems are not significantly associated with each other. Learners might be using a mobile phone but not for learning purposes. The items for social influence also refer to such examples as, "using an M-Learning system if my classmates use it", "if my instructors advise its use and helps in using it", or "if my associates thought I must use it for effective learning". Another influencing factor is, "if the significant people in my life considered I should be using it then I would or if my university supported and promoted its use". Fagan (2019) [1] found that social influence does not have a significant effect on the intention to use M-Learning, whereas it influences performance expectancy positively. Many studies examined the effect of social influence on the use of mobile learning $[10,11,13,23]$ The impact of social influence on M-Learning systems differed significantly in previous studies. Some studies have pointed out that there is a relationship between the two, while other studies have concluded that there is no relationship between the two factors. Our study further strengthened the second group and concluded that there is no significant association between social influence and the adoption of M-Learning systems.

Hypothesis 5 was supported, which indicates that facilitating conditions are highly, positively, and significantly associated with the use of M-Learning systems. The items for facilitating conditions include having the resources required to use M-Learning, having the necessary ICT infrastructure for the use of M-Leaning, having the requisite skills to access the course over the mobile, and the existence of a peer group to resolve M-Leaning queries; these factors have a greater positive impact on the adoption of M-Learning systems. Previous studies [10,13] have examined the effects of facilitating conditions on the use of M-Learning, and their findings are similar to the finding of the current study.

Previous studies have also analyzed the use of a mobile phone for learning $[4,9,23,32,34-36]$ and pointed out that perceived usefulness, perceived ease of use, attitude, social influence, and facilitating conditions are the most important constructs and explanatory variables for the adoption of M-Learning systems. Instead of five factors, the current study concludes that only four factors (i.e., perceived usefulness, perceived ease of use, attitude, and facilitating conditions) are the most influential factors in the adoption of M-learning systems.

\section{Conclusions}

A theoretical model for mobile learning was developed with the help of a systematic literature review and tested empirically. Theoretically, five constructs were identified as the most contributory towards the use of M-Learning by university students, i.e., perceived usefulness, perceived ease of use, attitude, social influence, and facilitating conditions, which were extracted from the technology acceptance model and unified theory of acceptance and use of technology model. The SEM outcome states that these five constructs explain $76 \%$ of the use of M-Learning. Among these five factors, facilitating conditions is the most important construct, explaining $76 \%$ of M-Learning use, followed by attitude at $10 \%$, perceived usefulness at $0.085 \%$, perceived ease of use at $0.031 \%$, and social influence at $-0.6 \%$. Empirical testing indicates that four constructs were significantly associated with mobile learning acceptance, namely perceived usefulness $(\beta=0.085, t=2.201$, and $p=0.028)$, perceived ease of use $(\beta=0.031, \mathrm{t}=1.688$, and $p=0.013)$, attitude $(\beta=0.100, \mathrm{t}=3.771$, and $p=0.037)$, and facilitating conditions $(\beta=0.765, \mathrm{t}=4.319$, and $p=0.001)$, whereas social influence was insignificant $(\beta=-0.061$, $\mathrm{t}=0.136$, and $p=0.256$ ) for mobile learning acceptance. The contribution of social influence towards the use of M-Learning was found to be minimal (negative); hence, it was neglected. Thus, finally, four constructs were considered important as determinants of M-Learning.

\section{Limitations and Future Scope}

The current study was limited to university students in the southern region of Saudi Arabia. Further studies should explore the phenomenon in a broader geographical context, with wider education disciplines, and with larger sample sizes. Multicriteria decision-making methodologies such 
as Analytic Hierarchy Process (AHP) and fuzzy AHP could be used to rank and prioritize different mobile learning factors. The included construct items explain only $76 \%$ of the use of M-Learning, so more external factors need to be included and examined to minimize the contribution of external factors.

Author Contributions: Conceptualization, Q.N.N. and M.M.A.; methodology, Q.N.N.; software, M.M.A.; validation, Q.N.N., M.M.A. and N.T.; formal analysis, Q.N.N.; writing —original draft preparation, Q.N.N. and M.M.A.; writing-review and editing, Q.N.N. and N.T.; supervision, N.T.; project administration, M.M.A.; funding acquisition, M.M.A. All authors have read and agreed to the published version of the manuscript.

Funding: This research was funded by Deanship of Scientific Research, King Khalid University, Kingdom of Saudi Arabia, and grant number GRP-138-40.

Acknowledgments: We would like to express our gratitude to Deanship of Scientific Research King Khalid University, Kingdom of Saudi Arabia for funding this work, as well as family, friends, and colleagues for their constant inspiration and encouragement.

Conflicts of Interest: The authors declare no conflict of interest.

\section{Appendix A}

Table A1. M-Learning factors and models.

\begin{tabular}{|c|c|c|c|c|}
\hline No & Research Title & M-Learning Factors & Model/Theory & Reference \\
\hline 1 & $\begin{array}{l}\text { Social, individual, } \\
\text { technological and } \\
\text { pedagogical factors } \\
\text { influencing mobile learning } \\
\text { acceptance in } \\
\text { higher education }\end{array}$ & $\begin{array}{l}\text { Pedagogical Factors } \\
\text { (Learning Content Quality, Interactivity) } \\
\text { Technological Factors } \\
\text { (Facilitating Conditions, User Interface, } \\
\text { Mobile Device Limitations) } \\
\text { Social Factors (Government Support, } \\
\text { Social Influence) } \\
\text { Individual Factors (Personal Innovativeness, } \\
\text { Self-Efficacy, Trust) } \\
\text { Perceived Ease of Use, } \\
\text { Perceived Usefulness }\end{array}$ & $\begin{array}{l}\text { Technology Acceptance } \\
\text { Model (TAM) and the } \\
\text { Unified Theory of } \\
\text { Acceptance and Use of } \\
\text { Technology (UTAUT) }\end{array}$ & [9] \\
\hline 2 & $\begin{array}{l}\text { Integrating Mobile Learning } \\
\text { to Learning Management } \\
\text { System in } \\
\text { Community College }\end{array}$ & $\begin{array}{l}\text { Performance Expectancy (PE), } \\
\text { Effort Expectancy (EE), Social Influence } \\
\text { (SI), Facilitating Conditions (FC), } \\
\text { Behavioral Intent (BI) }\end{array}$ & UTAUT & [13] \\
\hline 3 & $\begin{array}{l}\text { Factors Influencing Student } \\
\text { Acceptance of Mobile } \\
\text { Learning in Higher Education }\end{array}$ & $\begin{array}{l}\text { Adopted Unified Theory of Acceptance } \\
\text { and Use of Technology (UTAUT) Model }\end{array}$ & Extended UTAUT & [1] \\
\hline 4 & $\begin{array}{l}\text { Essential factors for the } \\
\text { application of } \\
\text { education information } \\
\text { system using mobile learning }\end{array}$ & $\begin{array}{l}\text { Ease of Use, Culture of Using M-Learning, } \\
\text { Behavioral Intention, Student Trust, } \\
\text { Usefulness, Student satisfaction, } \\
\text { Understanding of M-Learning }\end{array}$ & & [5] \\
\hline 5 & $\begin{array}{l}\text { Investigating university } \\
\text { students' intention to use } \\
\text { mobile learning management } \\
\text { systems in Sweden }\end{array}$ & $\begin{array}{l}\text { TAM Model (perceived usefulness and } \\
\text { perceived ease) + academic relevance, } \\
\text { university management support, } \\
\text { and perceived mobility }\end{array}$ & TAM & [4] \\
\hline 6 & $\begin{array}{l}\text { Designing for } \\
\text { sustainable mobile } \\
\text { learning-re-evaluating the } \\
\text { concepts "formal" } \\
\text { and "informal" }\end{array}$ & $\begin{array}{l}\text { Personalization (agency, customization), } \\
\text { Collaboration (conversation, } \\
\text { data sharing), } \\
\text { Authenticity (situatedness, contextualization) }\end{array}$ & $\begin{array}{l}\text { M-Learning } \\
\text { framework }\end{array}$ & [36] \\
\hline 7 & $\begin{array}{l}\text { Analysis of the essential } \\
\text { factors for the adoption of } \\
\text { mobile learning in } \\
\text { higher education }\end{array}$ & $\begin{array}{l}\text { Context, Trust factor, Personal characters } \\
\text { and features, Perceived usefulness factor, } \\
\text { ease of use factor, } \\
\text { Behavioral intention factor }\end{array}$ & Extended TAM & [10] \\
\hline 8 & $\begin{array}{l}\text { The Effects of Attitudinal, } \\
\text { Normative and Control } \\
\text { Beliefs on M-Learning } \\
\text { Adoption Among the } \\
\text { Students of Higher Education } \\
\text { in Pakistan }\end{array}$ & $\begin{array}{l}\text { Attitude (Perceived Ease of use, } \\
\text { Perceived usefulness) } \\
\text { Subjective norm (Instructors' readiness, } \\
\text { Students' readiness) } \\
\text { Perceived behavioral control } \\
\text { (Perceived Self efficacy, } \\
\text { Learning Autonomy) }\end{array}$ & $\begin{array}{l}\text { TAM and Theory of } \\
\text { Planned Behavior }\end{array}$ & [14] \\
\hline
\end{tabular}


Table A1. Cont.

\begin{tabular}{|c|c|c|c|c|}
\hline No & Research Title & M-Learning Factors & Model/Theory & Reference \\
\hline 9 & $\begin{array}{l}\text { Mobile lecturers, } \\
\text { mobile students: } \\
\text { an exploratory study in } \\
\text { a blended } \\
\text { architectural technology context }\end{array}$ & $\begin{array}{l}\text { Theoretical factors } \\
\text { Technology (Applications, } \\
\text { Device specifications, } \\
\text { Device types, Portability), } \\
\text { Outlook (Attitude, Perception, } \\
\text { Satisfaction, Mobile productivity, Usage, } \\
\text { Preferences, Usability, User experience, } \\
\text { Expectations, Immediacy), } \\
\text { Effectiveness, Convenience, Distractions, } \\
\text { Facilitation Safety and security } \\
\text { Capability Alignment, Digital difference, } \\
\text { Digital divide, Flexibility, } \\
\text { Mobile discussion, On-the-go } \\
\text { Interactivity, Information sharing, } \\
\text { Blended architectural technology context, } \\
\text { Motivation, Communication, } \\
\text { Connectivity, Social networking }\end{array}$ & & [37] \\
\hline 10 & $\begin{array}{l}\text { Examination of factors } \\
\text { influencing students and } \\
\text { faculty behavior towards } \\
\text { M-learning acceptance }\end{array}$ & $\begin{array}{l}\text { TAM constructs: Acceptance of m-learning } \\
\text { (Perceived Usefulness (PU), } \\
\text { Perceived Ease of Use (PEOU), } \\
\text { Attitude (ATT), and Behavioural } \\
\text { Intention (BI) } \\
\text { Generalized constructs: competency } \\
\text { (Prior experience (PE), SE (Self efficacy), } \\
\text { and Skill readiness (SK)) } \\
\text { Localized constructs: technological } \\
\text { readiness (device features usability (DFU), } \\
\text { service affordability and } \\
\text { availability (SAA)) }\end{array}$ & Extended TAM & [22] \\
\hline 11 & $\begin{array}{l}\text { Mobile learning in nursing } \\
\text { education: catering for } \\
\text { students and teachers ' needs }\end{array}$ & $\begin{array}{l}\text { Device usability (Portability, Information } \\
\text { availability, Psychological comfort, } \\
\text { Satisfaction, Information availability) } \\
\text { Interaction learning (Learner-content, } \\
\text { Learner-teacher, Learner-learner, } \\
\text { Learning communities) } \\
\text { Social technology (Device networking, } \\
\text { System connectivity) }\end{array}$ & $\begin{array}{l}\text { Rational Analysis of } \\
\text { Mobile Education } \\
\text { (FRAME) }\end{array}$ & [38] \\
\hline 12 & $\begin{array}{l}\text { Development and validation } \\
\text { of Mobile Learning } \\
\text { Acceptance Measure }\end{array}$ & $\begin{array}{l}\text { Flexibility, Suitability, Enjoyment, } \\
\text { Efficiency, Economic, Social }\end{array}$ & $\begin{array}{l}\text { Mobile learning Acceptance } \\
\text { Measure (MLAM) }\end{array}$ & e [23] \\
\hline 13 & $\begin{array}{l}\text { Cultural Factors that } \\
\text { Influence M-Learning for } \\
\text { Female University Students: } \\
\text { A Saudi Arabian Case Study }\end{array}$ & $\begin{array}{l}\text { Performance expectancy, } \\
\text { Effort expectancy, Social Influence, } \\
\text { Personal, Self-management of learning, } \\
\text { behavioral intention to use M-learning }\end{array}$ & UTAUT & [11] \\
\hline 14 & $\begin{array}{l}\text { Learning with } \\
\text { mobile technologies- } \\
\text { Students' behavior }\end{array}$ & $\begin{array}{l}\text { Performance expectancy or Perceived } \\
\text { Usefulness, Effort Expectancy or } \\
\text { Perceived Ease of Use, Attitude toward } \\
\text { using technology, Social Influence, } \\
\text { Facilitating conditions, Self-efficacy, } \\
\text { Anxiety, Behavioral intention to use the } \\
\text { new technology, Reliability, } \\
\text { and Recommendation }\end{array}$ & TAM and UTAUT & [33] \\
\hline 15 & $\begin{array}{l}\text { Management's Perspective } \\
\text { on Critical Success Factors } \\
\text { Affecting Mobile Learning in } \\
\text { Higher Education } \\
\text { Institutions-An } \\
\text { Empirical Study }\end{array}$ & $\begin{array}{l}\text { University organizational structure, } \\
\text { University organizational culture, } \\
\text { University commitment to m-Learning, } \\
\text { University organizational learning } \\
\text { practices, University change management } \\
\text { practices, University conflict } \\
\text { management practices }\end{array}$ & & [34] \\
\hline 16 & $\begin{array}{l}\text { Towards a quality model of } \\
\text { technical aspects for mobile } \\
\text { learning services: } \\
\text { An empirical investigation }\end{array}$ & $\begin{array}{l}\text { Availability, Quick response, Flexibility, } \\
\text { Scalability, Connectivity, Efficiency and } \\
\text { performance, Reliability, Functionality, } \\
\text { Usability, Maintainability, } \\
\text { User interface, Security }\end{array}$ & $\begin{array}{c}\text { DeLone and McLean IS } \\
\text { success model }\end{array}$ & [15] \\
\hline
\end{tabular}


Table A1. Cont.

\begin{tabular}{|c|c|c|c|c|}
\hline No & Research Title & M-Learning Factors & Model/Theory & Reference \\
\hline 17 & $\begin{array}{l}\text { Exploring students' } \\
\text { awareness and perceptions: } \\
\text { Influencing factors and } \\
\text { individual differences driving } \\
\text { m-learning adoption }\end{array}$ & $\begin{array}{l}\text { M-learning services, Perceived usefulness, } \\
\text { Social Influence, Perceived ease of use, } \\
\text { Mobile limitations, Behavioral intention } \\
\text { to use M-learning }\end{array}$ & TAM and UTAUT & [39] \\
\hline 18 & $\begin{array}{l}\text { Understanding mobile } \\
\text { learning adoption in } \\
\text { higher education }\end{array}$ & $\begin{array}{l}\text { Attitude, Behavioral intention, } \\
\text { Task characteristics, } \\
\text { Technology characteristics, } \\
\text { Task-technology fit }\end{array}$ & Task-technology fit (TTF) & [16] \\
\hline 19 & & $\begin{array}{l}\text { Technology characteristics, } \\
\text { Task characteristics, Task-technology fit, } \\
\text { Attitude, Behavioral intention }\end{array}$ & & [16] \\
\hline 20 & $\begin{array}{l}\text { An Empirical Study of } \\
\text { Factors Driving the } \\
\text { Adoption of } \\
\text { Mobile Learning in Omani } \\
\text { Higher Education }\end{array}$ & $\begin{array}{l}\text { Enjoyment, Economic, Suitability, Social, } \\
\text { Usefulness, Ease of use, } \\
\text { Willingness to Adopt }\end{array}$ & TAM & [21] \\
\hline 21 & $\begin{array}{l}\text { Towards Acceptance of } \\
\text { M-Learning Approach in } \\
\text { Higher Education in } \\
\text { Saudi Arabia }\end{array}$ & $\begin{array}{l}\text { Performance Expectancy, } \\
\text { Effort Expectancy, Lecturers' Influence, } \\
\text { Self-Management of Learning, } \\
\text { Behavioral Intention }\end{array}$ & UTAUT & [12] \\
\hline 22 & $\begin{array}{l}\text { The effects of the intended } \\
\text { behavior of students in the } \\
\text { use of M-learning }\end{array}$ & $\begin{array}{l}\text { Performance Expectancy, Effort } \\
\text { Expectancy, Lecturers' Influence, } \\
\text { Quality of service, } \\
\text { Personal innovativeness, } \\
\text { Behavioral Intention }\end{array}$ & UTAUT & [35] \\
\hline 23 & $\begin{array}{l}\text { Social and individual } \\
\text { antecedents of m-learning } \\
\text { adoption in Iran }\end{array}$ & $\begin{array}{l}\text { Self-efficacy, Absorptive capacity, } \\
\text { Individual mobility, } \\
\text { Personal innovativeness, Perceived image, } \\
\text { Subjective norms, Perceived ease } \\
\text { usefulness, Perceived ease of use }\end{array}$ & $\begin{array}{l}\text { TAM and } \\
\text { Expectation-Confirmation } \\
\text { Theory (ECT) }\end{array}$ & [17] \\
\hline 24 & $\begin{array}{l}\text { Determining the factors } \\
\text { influencing students' } \\
\text { intention to use m-learning in } \\
\text { Jordan higher education }\end{array}$ & $\begin{array}{l}\text { Facilitating Conditions, Self-Efficiency, } \\
\text { Perceived ease of use, } \\
\text { Perceived usefulness, Service quality, } \\
\text { Behavioral intention }\end{array}$ & TAM and QoS & [40] \\
\hline 25 & $\begin{array}{l}\text { An Examination of the Prior } \\
\text { Use of E-Learning Within } \\
\text { an Extended } \\
\text { Technology Acceptance } \\
\text { Model and the Factors That } \\
\text { Influence the Behavioral } \\
\text { Intention of Users to } \\
\text { Use M-Learning }\end{array}$ & $\begin{array}{l}\text { Self-efficacy, Perceived usefulness, } \\
\text { subjective norms, attitude, } \\
\text { behavioral intention, perceived ease of } \\
\text { use, prior use of e-learning }\end{array}$ & Extended TAM & [24] \\
\hline 26 & $\begin{array}{l}\text { Predicting the drivers of } \\
\text { behavioral intention to use } \\
\text { mobile learning: } \\
\text { A hybrid SEM-Neural } \\
\text { Networks approach }\end{array}$ & $\begin{array}{l}\text { perceived ease of use, perceived } \\
\text { usefulness, personal innovativeness in } \\
\text { information technology, social influence }\end{array}$ & Extended TAM & [41] \\
\hline 27 & $\begin{array}{l}\text { Determinants of Mobile } \\
\text { Learning Adoption: An } \\
\text { Empirical Analysis }\end{array}$ & $\begin{array}{l}\text { PU, PEoU, Sub Norms, Intention to adopt } \\
\text { m-learning }\end{array}$ & TAM & [42] \\
\hline 28 & $\begin{array}{l}\text { Factors driving the adoption } \\
\text { of m-learning: } \\
\text { An empirical study }\end{array}$ & $\begin{array}{l}\text { PEoU, Personal Innovativeness, } \\
\text { Near term Usefulness, Long term } \\
\text { Usefulness, BI }\end{array}$ & TAM & [43] \\
\hline 29 & $\begin{array}{l}\text { Investigating the } \\
\text { determinants and age and } \\
\text { gender differences in the } \\
\text { acceptance of mobile learning }\end{array}$ & $\begin{array}{l}\text { Performance expectancy, } \\
\text { Effort expectancy, Social Influence, } \\
\text { Perceived playfulness, } \\
\text { Self-management of learning }\end{array}$ & UTAUT & [44] \\
\hline
\end{tabular}


Table A2. Construct measurements and sources.

\begin{tabular}{|c|c|c|c|}
\hline Construct & Item & Measure & Source \\
\hline \multirow{5}{*}{ Perceived Usefulness } & PUS1 & M-Learning is beneficial for my studies. & [39] \\
\hline & PUS2 & M-Learning assists me to achieve learning tasks more quickly. & [39] \\
\hline & PUS3 & Using M-Learning will raise my learning efficiency. & [39] \\
\hline & PUS4 & M-Learning improves my association with instructors and classmates. & [39] \\
\hline & PUS5 & M-Learning allows instant access to study issues regardless of my location. & [39] \\
\hline \multirow{6}{*}{ Perceived Ease of Use } & PEU1 & M-Learning system is flexible and easy to use. & [39] \\
\hline & PEU2 & Use of the M-Learning system does not need much efforts. & [39] \\
\hline & PEU3 & It is easy to become skillful at using M-Learning system. & [39] \\
\hline & PEU4 & It is easy to access data using the M-Learning system. & [39] \\
\hline & PEU5 & It is easy to get things done using M-Learning tools then by doing otherwise. & [39] \\
\hline & ATT1 & I like working with the system. & [45] \\
\hline \multirow{3}{*}{ Attitude } & ATT2 & The system makes work more interesting. & [45] \\
\hline & ATT3 & Working with the system is fun. & [45] \\
\hline & ATT4 & Using the system is a good idea. & [45] \\
\hline \multirow{5}{*}{ Social Influence } & SIN1 & I will use mobile learning if my colleagues use it. & [45] \\
\hline & SIN2 & $\begin{array}{l}\text { If my lecturers advise and help in using, then I would use the } \\
\text { M-Learning system. }\end{array}$ & [39] \\
\hline & SIN3 & $\begin{array}{l}\text { I would use the M-Learning program when my colleagues thought I must } \\
\text { use it for effective learning. }\end{array}$ & [39] \\
\hline & SIN4 & $\begin{array}{l}\text { I would use the M-Learning system when people, most of whom are } \\
\text { relevant to me, think I should be using it. }\end{array}$ & [39] \\
\hline & SIN5 & $\begin{array}{l}\text { I would use the M-Learning system if my university supports and } \\
\text { promotes its use. }\end{array}$ & [39] \\
\hline \multirow{4}{*}{ Facilitating Conditions } & FCO1 & I have the resource required for use with M-Learning. & [9] \\
\hline & $\mathrm{FCO} 2$ & There is the necessary ICT infrastructure for the use of M-Leaning. & [9] \\
\hline & FCO3 & I had the requisite skills to use the course over mobile. & [13] \\
\hline & FCO4 & $\begin{array}{l}\text { There is a specific person from a supportive group to help with troubles } \\
\text { using M-Leaning. }\end{array}$ & [13] \\
\hline \multirow{4}{*}{ Use of M-Learning System } & UMS1 & I use M-Learning daily. & \\
\hline & UMS2 & I plan to use M-Learning in my studies. & [35] \\
\hline & UMS3 & I recommend M-Learning for others use. & [9] \\
\hline & UMS4 & I believe that using M-Learning is always a pleasurable experience for me. & [9] \\
\hline
\end{tabular}

\section{References}

1. Fagan, M.H. Factors Influencing Student Acceptance of Mobile Learning in Higher Education. Comput. Sch. 2019, 36, 105-121. [CrossRef]

2. Naveed, Q.N.; Qureshi, M.R.N.; Tairan, N.; Mohammad, A.; Shaikh, A.; Alsayed, A.O.; Shah, A.; Alotaibi, F.M. Evaluating critical success factors in implementing E-learning system using multi-criteria decision-making. PLOS ONE 2020, 15, e0231465. [CrossRef]

3. Almaiah, M.A.; Alamri, M.M.; Al-Rahmi, W. Applying the UTAUT Model to Explain the Students' Acceptance of Mobile Learning System in Higher Education. IEEE Access 2019, 7, 174673-174686. [CrossRef]

4. Saroia, A.I.; Shang, G. Investigating university students' intention to use mobile learning management systems in Sweden. Innov. Educ. Teach. Int. 2018, 56, 569-580. [CrossRef]

5. Hamidi, H.; Jahanshaheefard, M. Essential factors for the application of education information system using mobile learning: A case study of students of the university of technology. Telemat. Inform. 2019, 38, 207-224. [CrossRef]

6. Almaiah, M.A.; Jalil, M.A.; Man, M. Extending the TAM to examine the effects of quality features on mobile learning acceptance. J. Comput. Educ. 2016, 3, 453-485. [CrossRef]

7. Calabrese, A.; Costa, R.; Rosati, F. Gender differences in customer expectations and perceptions of corporate social responsibility. J. Clean. Prod. 2016, 116, 135-149. [CrossRef]

8. Naveed, Q.N.; Qureshi, M.R.N.; Alsayed, A.O.; Muhammad, A.; Sanober, S.; Shah, A. Prioritizing Barriers of E-Learning for Effective Teaching-Learning using Fuzzy Analytic Hierarchy Process (FAHP). In Proceedings of the 4th IEEE International Conference on Engineering Technologies and Applied Sciences (ICETAS) 2017, Salmabad, Bahrain, 29 November-1 December 2017.

9. Chavoshi, A.; Hamidi, H. Social, individual, technological and pedagogical factors influencing mobile learning acceptance in higher education: A case from Iran. Telemat. Inform. 2019, 38, 133-165. [CrossRef] 
10. Hamidi, H.; Chavoshi, A. Analysis of the essential factors for the adoption of mobile learning in higher education: A case study of students of the University of Technology. Telemat. Inform. 2018, 35, 1053-1070. [CrossRef]

11. Badwelan, A.; Bahaddad, A.A. Cultural Factors that Influence M-Learning for Female University Students: A Saudi Arabian Case Study. Int. J. Comput. Appl. 2017, 166, 21-32. [CrossRef]

12. Badwelan, A.; Drew, S.; Bahaddad, A.A. Towards Acceptance M-Learning Approach in Higher Education in Saudi Arabia. Int. J. Bus. Manag. 2016, 11, 12. [CrossRef]

13. Hu, X.; Ng, J.; Tsang, K.K.Y.; Chu, S.K.W. Integrating Mobile Learning to Learning Management System in Community College. Community Coll. J. Res. Pr. 2019, 1-16. [CrossRef]

14. Raza, S.A.; Umer, A.; Qazi, W.; Makhdoom, M. The Effects of Attitudinal, Normative, and Control Beliefs on M-Learning Adoption among the Students of Higher Education in Pakistan. J. Educ. Comput. Res. 2017, 56, 563-588. [CrossRef]

15. Sarrab, M.; Elbasir, M.; Alnaeli, S. Towards a quality model of technical aspects for mobile learning services: An empirical investigation. Comput. Hum. Behav. 2016, 55, 100-112. [CrossRef]

16. Gan, C.; Li, H.; Liu, Y.; Thomsett-Scott, B. Understanding mobile learning adoption in higher education. Electron. Libr. 2017, 35, 846-860. [CrossRef]

17. Mohammadi, H. Social and individual antecedents of m-learning adoption in Iran. Comput. Hum. Behav. 2015, 49, 191-207. [CrossRef]

18. Davis, F.D. Perceived usefulness, perceived ease of use, and user acceptance of information technology. MIS Q. 1989, 13, 319-340. [CrossRef]

19. Venkatesh, V.; Morris, M.G.; Davis, G.B.; Davis, F.D. User acceptance of information technology: Toward a unified view. MIS Q. 2003, 27, 425-478. [CrossRef]

20. Ahmad, N.; Quadri, N.N.; Qureshi, M.R.; Alam, M.M. Relationship Modeling of Critical Success Factors for Enhancing Sustainability and Performance in E-Learning. Sustainability 2018, 10, 4776. [CrossRef]

21. Sarrab, M.; Al Shibli, I.; Badursha, N. An Empirical Study of Factors Driving the Adoption of Mobile Learning in Omani Higher Education. Int. Rev. Res. Open Distrib. Learn. 2016, 17. [CrossRef]

22. Bakhsh, M.; Mahmood, A.; Sangi, N.A. Examination of factors influencing students and faculty behavior towards m-learning acceptance. Int. J. Inf. Learn. Technol. 2017, 34, 166-188. [CrossRef]

23. Sharma, S.K.; Sarrab, M.; Al-Shihi, H. Development and validation of Mobile Learning Acceptance Measure. Interact. Learn. Environ. 2016, 25, 847-858. [CrossRef]

24. Abramson, J.; Dawson, M.; Stevens, J. An Examination of the Prior Use of E-Learning within an Extended Technology Acceptance Model and the Factors That Influence the Behavioral Intention of Users to Use M-Learning. SAGE Open 2015, 5. [CrossRef]

25. Churchill, G.A.; Iacobucci, D. Marketing Research: Methodological Foundations; Dryden Press: New York, NY, USA, 2006.

26. Hair, J.; Black, W.; Babin, B.; Anderson, R. Exploratory Factor Analysis. Multivariate Data Analysis, 7th ed.; UK Pearson Educ.: Harlow, UK, 2014.

27. Fornell, C.; Larcker, D.F. Evaluating Structural Equation Models with Unobservable Variables and Measurement Error. J. Mark. Res. 1981, 18, 39-50. [CrossRef]

28. Henseler, J.; Ringle, C.M.; Sarstedt, M. A new criterion for assessing discriminant validity in variance-based structural equation modeling. J. Acad. Mark. Sci. 2014, 43, 115-135. [CrossRef]

29. Hair, J.F.; Risher, J.J.; Sarstedt, M.; Ringle, C.M. When to use and how to report the results of PLS-SEM. Eur. Bus. Rev. 2019, 31, 2-24. [CrossRef]

30. Kline, R.B. Principles and Practice of Structural Equation Modeling; Guilford Publications: New York, NY, USA, 2015.

31. Cenfetelli, R.T.; Bassellier, G. Interpretation of Formative Measurement in Information Systems Research. MIS Q. 2009, 33, 689-707. [CrossRef]

32. Cheng, Y.-M. Towards an understanding of the factors affecting m-learning acceptance: Roles of technological characteristics and compatibility. Asia Pac. Manag. Rev. 2015, 20, 109-119. [CrossRef]

33. Azizi, S.M.; Khatony, A. Investigating factors affecting on medical sciences students' intention to adopt mobile learning. BMC Med. Educ. 2019, 19, 381. [CrossRef]

34. Alrasheedi, M.; Capretz, L.F.; Raza, A. Management's Perspective on Critical Success Factors Affecting Mobile Learning in Higher Education Institutions-An Empirical Study. J. Educ. Comput. Res. 2015, 54, 253-274. [CrossRef] 
35. IMilošević, I.; Živković, D.; Manasijevic, D.; Nikolić, D. The effects of the intended behavior of students in the use of M-learning. Comput. Hum. Behav. 2015, 51, 207-215. [CrossRef]

36. Viberg, O.; Andersson, A.; Wiklund, M. Designing for sustainable mobile learning-Re-evaluating the concepts "formal" and "informal". Interact. Learn. Environ. 2018, 1-12. [CrossRef]

37. Harpur, P. Mobile lecturers, mobile students: An exploratory study in a blended architectural technology context. J. Enterp. Inf. Manag. 2017, 30, 748-778. [CrossRef]

38. Li, K.C.; Lee, L.Y.-K.; Wong, S.-L.; Yau, S.Y.; Wong, B.T.-M. Mobile learning in nursing education: Catering for students and teachers' needs. Asian Assoc. Open Univ. J. 2017, 12, 171-183. [CrossRef]

39. Sabah, N. Exploring students' awareness and perceptions: Influencing factors and individual differences driving m-learning adoption. Comput. Hum. Behav. 2016, 65, 522-533. [CrossRef]

40. Althunibat, A. Determining the factors influencing students' intention to use m-learning in Jordan higher education. Comput. Hum. Behav. 2015, 52, 65-71. [CrossRef]

41. Tan, G.W.-H.; Ooi, K.-B.; Leong, L.-Y.; Lin, B. Predicting the drivers of behavioral intention to use mobile learning: A hybrid SEM-Neural Networks approach. Comput. Hum. Behav. 2014, 36, 198-213. [CrossRef]

42. Tan, G.W.-H.; Ooi, K.-B.; Sim, J.-J.; Phusavat, K. Determinants of mobile learning adoption: An empirical analysis. J. Comput. Inf. Syst. 2012, 52, 82-91.

43. Liu, Y.; Li, H.; Carlsson, C. Factors driving the adoption of m-learning: An empirical study. Comput. Educ. 2010, 55, 1211-1219. [CrossRef]

44. Wang, Y.-S.; Wu, M.-C.; Wang, H.-Y. Investigating the determinants and age and gender differences in the acceptance of mobile learning. Br. J. Educ. Technol. 2009, 40, 92-118. [CrossRef]

45. Briz-Ponce, L.; Pereira, A.; Carvalho, L.; Juanes-Méndez, J.A.; Garcia, B.A. Learning with mobile technologies-Students' behavior. Comput. Hum. Behav. 2017, 72, 612-620. [CrossRef]

Publisher's Note: MDPI stays neutral with regard to jurisdictional claims in published maps and institutional affiliations. 